\title{
Influence of toothbrushing on enamel softening and abrasive wear of eroded bovine enamel: an in situ study
}

\section{Influência da escovação no amolecimento superficial do esmalte e desgaste do esmalte bovino erodido: um estudo in situ}

\author{
Daniela Rios* \\ Heitor Marques Honório** \\ Ana Carolina Magalhães*** \\ Marilia Afonso Rabelo Buzalaf**** \\ Regina Guenka Palma-Dibb***** \\ Maria Aparecida De Andrade Moreira Machado****** \\ Salete Moura Bonifácio da Silva ${ }^{* * * * *}$
}

\begin{abstract}
This study assessed the surface softening and abrasive wear of eroded bovine enamel with or without the influence of toothbrushing. Five volunteers took part in this in situ study of 5 days. They wore acrylic palatal appliances containing 6 bovine enamel blocks divided in two rows with 3 blocks, which corresponded to the studied groups: erosion without toothbrushing (GI) and erosion with toothbrushing (GII). The blocks were subjected to erosion by immersion of the appliances in a cola drink for 10 minutes, 4 times a day. After that, no treatment was performed in one row (GI), whereas the other row was brushed (GII). The appliance was then replaced into the mouth. Enamel alterations were determined using profilometry and microhardness tests. Data were tested using paired Student's $t$ test $(\mathrm{p}<0.05)$. The mean wear values $(\mu \mathrm{m})$ and percentage of superficial microhardness change (\%SMHC) were respectively: GI - $2.77 \pm 1.21 / 91.61 \pm 3.68$ and GII $-3.80 \pm 0.91 / 58.77 \pm 11.47$. There was a significant difference in wear $(p=0.001)$ and \%SMHC $(p=0.001)$ between the groups. It was concluded that the wear was more pronounced when associated to toothbrushing abrasion. However, toothbrushing promoted less \% SMHC due to the removal of the altered superficial enamel layer.
\end{abstract}

DESCRIPTORS: Tooth erosion; Tooth abrasion; Beverages.

\begin{abstract}
RESUMO: Este estudo avaliou o amolecimento superficial e o desgaste do esmalte bovino erodido com ou sem influência da escovação. Cinco voluntários fizeram parte deste estudo in situ de 5 dias. Eles usaram aparelhos palatinos de acrílico contendo 6 blocos de esmalte bovino divididos em 2 fileiras com 3 blocos, cada fileira correspondeu a um grupo em estudo: erosão sem escovação dentária (GI) e erosão seguida de escovação dentária (GII). Os blocos foram submetidos à erosão por imersão do aparelho em uma bebida à base de cola por 10 minutos, 4 vezes ao dia. Depois disso, nenhum tratamento foi realizado em uma fileira (GI), enquanto a outra fileira foi escovada (GII). Em seguida, o aparelho foi recolocado na boca. Alterações do esmalte foram determinadas por teste de perfilometria e microdureza. Os dados foram analisados usando-se teste $t$ de Student $(\mathrm{p}<0,05)$. O valor médio de desgaste $(\mu \mathrm{m})$ e da porcentagem de perda de microdureza superficial (\%PDS) foi respectivamente: GI - 2,77 $\pm 1,21 / 91,61 \pm 3,68$ e GII - 3,80 $\pm 0,91 / 58,77 \pm 11,47$. Houve uma diferença estatisticamente significante no desgaste $(p=0,001)$ e na $\% \operatorname{PDS}(\mathrm{p}=0,001)$ entre grupos. Conclui-se que o desgaste foi mais pronunciado quando associado à abrasão pela escovação. Entretanto, a escovação promoveu menor \%PDS, devido à remoção da camada de esmalte superficial alterada.
\end{abstract}

DESCRITORES: Erosão de dente; Abrasão dentária; Bebidas.

\section{INTRODUCTION}

While the incidence of the major dental disease, caries, has declined in developed countries ${ }^{27}$, other dental lesions such as erosion are becoming increasingly important ${ }^{15}$. Dental erosion is defined as the loss of tooth substance by chemical processes not involving bacteria ${ }^{20}$ caused by a variety

\footnotetext{
* Assistant Professor, Department of Pediatric Dentistry, School of Dentistry of Maringá, Maringá University Center.

** PhD Student, Department of Pediatric Dentistry, School of Dentistry of Bauru; ****Associate Professor, Department of Biological Science, School of Dentistry of Bauru; ${ }^{* * * * *}$ Associate Professors, Department of Pediatric Dentistry, School of Dentistry of Bauru; ${ }_{* * * * *}$ Associate Professor, Department of Restorative Dentistry, School of Dentistry of Ribeirão Preto - University of São Paulo. *** PhD Student, Department of Pediatric Dentistry, School of Dentistry of Araçatuba, São Paulo State University.
} 
Rios D, Honório HM, Magalhães AC, Buzalaf MAR, Palma-Dibb RG, Machado MAAM, Silva SMB. Influence of toothbrushing on enamel softening and abrasive wear of eroded bovine enamel: an in situ study. Braz Oral Res 2006;20(2):148-54.

of extrinsic and intrinsic factors ${ }^{9,25}$.

Intrinsic factors are the result of endogenous acids, generally gastric acids that become in contact with dental surface during nervous anorexia, nervous bulimia and gastroesophagic disturbances ${ }^{28,29}$. Extrinsic factors are related to frequent consumption of acidic foodstuffs or beverages and exposure to acidic contaminants in the working environment ${ }^{22}$. In modern societies the extrinsic factors are becoming more important, due to the increased consumption of acidic drinks as soft drinks, sport drinks, fruit juices and fruit teas ${ }^{22}$.

The acidic attack leads to irreversible loss of dental hard tissue accompanied by a demineralization and softening of the surface $e^{2,9,17,25}$. This softened zone, particularly of enamel, appears to be more susceptible to removal by mechanical forces, like attrition and abrasion, which have little or no effect on the intact tissues ${ }^{1,4,5,8,18}$. Toothbrushing is a very important procedure to prevent dental caries. On the other hand it represents a mechanical force that can led to abrasion. Thus, the analysis of alterations that can be promoted by toothbrushing of previously eroded enamel is important and necessary.

The methods used for measurement of the superficial alterations of dental enamel can be quantitative (superficial microhardness, profilometry) and qualitative (scanning electron microscopy) ${ }^{14}$. Microhardness testing permits the measurement of the degree of softening of the surface, but does not allow the quantification of the height of surface loss. The profilometric method uses a depth-sensing instrument, which gives the height of this surface loss. Since the dental enamel can be softened (altering the microhardness) in association with dental wear, a combined study, using microhardness and profilometry would be able to quantify the alterations resulted from erosion and abrasion ${ }^{6,14}$.

Taking into account the association between erosion and abrasion and the importance of combined methodologies, the purpose of this study was to assess in situ the surface softening and abrasive wear of eroded bovine enamel with or without the influence of toothbrushing, by using profilometric and microhardness analyses.

\section{MATERIALS AND METHODS Experimental design}

This in situ study was approved by the Research and Ethics Committee, School of Dentistry of Bauru, University of São Paulo. Five healthy adult volunteers with a mean age of $23 \mathrm{yr}$ (range
19-28 yr) (Figure 1I), with normal salivary flow $(1 \mathrm{ml} / \mathrm{min}, \mathrm{pH} 7.0)$, and residing in a fluoridated area $(0.70 \mathrm{mgF} / \mathrm{L})$ took part in this study, during 5 days ${ }^{11}$. They wore acrylic palatal appliances, which contained two rows of 3 bovine dental enamel blocks each. The rows corresponded to one of these conditions: erosion without toothbrushing (GI) and erosion with toothbrushing (GII). The use of two conditions in the same intraoral palatal appliance was supported by the absence of a cross-effect in previous studies ${ }^{5,15,21}$. Enamel mineral loss was determined by profilometric and surface microhardness tests. Each group comprised 5 experimental units (volunteers), which were compared using paired Student's $t$ test.

\section{Enamel blocks and palatal appliance preparation}

Sixty enamel blocks (4 4 × $3 \mathrm{~mm})$ were prepared from bovine incisors sterilized by storage in a $2 \%$ formaldehyde solution ( $\mathrm{pH} 7.0$ ) for 30 days at room temperature ${ }^{11}$. Using one diamond disk (Isomet 1000; Buehler, Lake Bluff, IL, USA) the crowns were sectioned from the roots (Figure 1A). Next, using two parallel diamond disks separated by a 4-mm spacer, one slice was cut from the crown of each bovine incisor (Figure 1B). The enamel surface of the blocks (Figure 1C) was ground flat with water-cooled carborundum discs $(320,600$ and 1,200 grades of $\mathrm{Al}_{2} \mathrm{O}_{3}$ papers; Buehler, Lake Bluff, IL, USA), and polished with felt paper wet by diamond spray $(1 \mu \mathrm{m}$; Buehler) (Figures 1D and 1E) for surface microhardness determination (five indentations in different regions of the blocks, 25 g, 5 s, HMV-2000; Shimadzu Corporation, Tokyo, Japan) (Figure 1F).

Thirty blocks, with a mean (SD) surface microhardness of $353( \pm 23) \mathrm{KHN}$, were randomly divided into two groups. In order to maintain reference surfaces for lesion depth determination, two layers of nail varnish were applied on half of the surface of each block (Figure 1G).

On the left and right sides of the intraoral palatal appliances, 6 cavities of $5 \times 5 \times 3 \mathrm{~mm}$ were made, and into each of them, one block of enamel was randomly fixed with wax (Figure $1 \mathrm{H}$ ). The position of two groups (right or left) on the appliance was randomly chosen.

\section{Treatments}

During the experimental phase, the volunteers brushed their teeth with fluoride-free dentifrice ${ }^{6}$. The palatal device was worn for five consecutive 
Rios D, Honório HM, Magalhães AC, Buzalaf MAR, Palma-Dibb RG, Machado MAAM, Silva SMB. Influence of toothbrushing on enamel softening and abrasive wear of eroded bovine enamel: an in situ study. Braz Oral Res 2006;20(2):148-54.

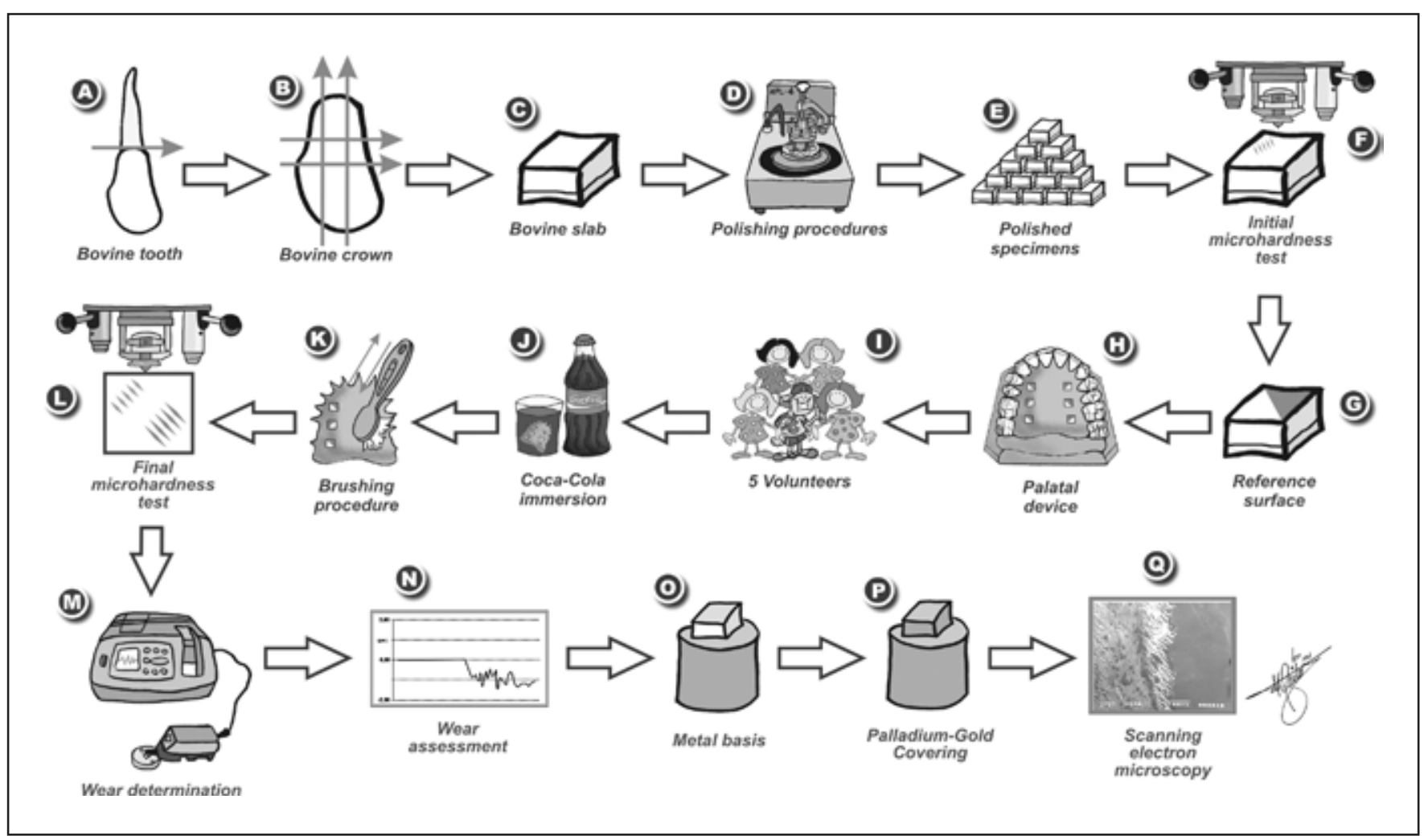

FIGURE 1 - Schematic illustration of the experimental sequence.

days $^{16,30}$. On the first 12 hours, specimens were not subjected to erosive and abrasive processes, to allow the formation of a salivary pellicle ${ }^{15}$. On the following 5 days, erosive and abrasive challenges were made extraorally 4 times a day and at predetermined times $(8: 00,12: 00,16: 00$ and 20:00 h) $)^{5,16,30}$.

In order to submit the enamel blocks to erosion, the volunteers were instructed to remove the appliance and immerse it in a cup containing $150 \mathrm{ml}$ of a freshly opened bottle of Coke ${ }^{\circledR}(\mathrm{pH} 2.8$, Spal, Porto Real, RJ, Brazil) for 10 minutes (Figure $1 \mathrm{~J})^{3,5}$. After that, no treatment was performed in one row (GI), whereas the other row (GII) was immediately brushed by the volunteers (Figure $1 \mathrm{~K}$ ). The brushing procedure consisted of 30 extraoral brushing strokes with a soft end-rounded toothbrush (Bitufo; Sanifil, Jundiai, SP, Brazil) with a small portion (approximately $0.3 \mathrm{~g}$ ) of the dentifrice without fluoride $\left(\right.$ Crest $^{\circledR}, \mathrm{pH} 6.8$, silica as abrasive) ${ }^{7}$. Volunteers were trained and instructed to carefully perform this procedure and to avoid a carry-across effect of the treatments. The brushed blocks were washed under deionized water and before the appliance was replaced into the mouth, the volunteers were instructed to take one sip of the beverage ${ }^{24}$.

The volunteers received instructions to wear the appliances continuously, including at night, but to remove them during meals (3 times a day), when oral hygiene was performed ${ }^{11,15}$. Plaque control on the blocks was achieved by dipping the appliance in $0.2 \%$ chlorhexidine gluconate solution ( $\mathrm{pH} 6.8$ ) for 5 minutes at the end of each study day ${ }^{16,30}$.

\section{Wear assessment}

After 5 days, the volunteers stopped wearing the appliances. The enamel blocks were removed from the appliances and the nail varnish over the surfaces was carefully cleaned with acetone-soaked cotton wool ${ }^{4}$. The blocks were dried and the enamel wear was determined in relation to the reference surface, by profilometry using a rugosimeter (Hommel Tester T1000, VS, Schwenningen, Germany) (Figures $1 \mathrm{M}$ and $1 \mathrm{~N}$ ). Five readings were performed on each specimen through a scanning from the reference to the exposed surface. The average wear depth of each group by volunteer (experimental unit) was computed using the 15 readings per- 
Rios D, Honório HM, Magalhães AC, Buzalaf MAR, Palma-Dibb RG, Machado MAAM, Silva SMB. Influence of toothbrushing on enamel softening and abrasive wear of eroded bovine enamel: an in situ study. Braz Oral Res 2006;20(2):148-54.

formed in micrometers $(\mu \mathrm{m})$ : three blocks $\mathrm{x}$ five readings.

\section{Percentage of superficial microhardness change assessment}

After the wear assessment, enamel surface microhardness was measured as described earlier (Figure 1L) and an average per volunteer was obtained. Ten indentations on each specimen were made, five on the previously protected enamel surface (SMH) and five on the experimental area $\left(\mathrm{SMH}_{1}\right)$. Using these measurements, the percentage of superficial microhardness change $(\% \mathrm{SMHC})$ was calculated $\left(\% \mathrm{SMHC}=\left[\left[\mathrm{SMH}_{1}{ }^{-}\right.\right.\right.$ $\mathrm{SMH}] / \mathrm{SMH}] \times 100)$.

\section{Scanning electron microscopy}

Four specimens whose wear and \%SMHC values were closest to the mean of each group were selected for scanning electron microscopic observations. The specimens were mounted and covered with palladium-gold by ion sputtering in a Hammer VI cathodic evaporator (Anatech LTD, Alexandria, USA) (Figures $1 O$ and $1 \mathrm{P}$ ). Then, they were studied and photographed in a JEOL JSM T220A scanning electron microscope (Tokyo, Japan) operating at $15 \mathrm{kV}$ (Figure 1Q).

\section{Statistical analysis}

Each group comprised 5 experimental units (volunteers), which were statistically analised. First, the assumptions of equality of variances and

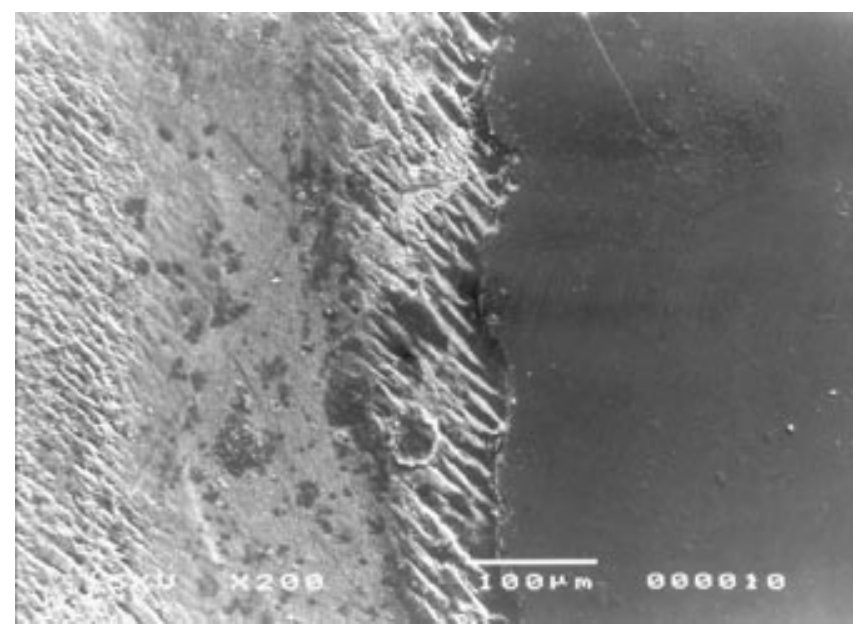

FIGURE 2 - Control-test area of specimen from group I (erosion). The bar represents $100 \mu \mathrm{m}(200 \mathrm{X})$. normal distribution of errors were checked for the response variables tested. Since the assumptions were satisfied, the paired Student's $t$ test was carried out for statistical comparisons. The significance level was set at $5 \%$.

\section{RESULTS}

All five volunteers completed the study. Table 1 shows that Group I (erosion) had a significantly higher \%SMHC than Group II (erosion plus abrasion) $(p=0.001)$. Nevertheless the wear was less pronounced for Group I when compared to Group II ( $\mathrm{p}=0.001)$.

The scanning electron microscopy images permitted the visualization of a distinct line of demarcation at the test-control margin on both groups (Figures 2 and 3). Specimen surfaces that had been covered with nail varnish did not show alterations. At higher magnification of the test area of group I (erosion), prism core dissolution was observed (Figure 4). However, the test area of group II (erosion plus toothbrushing) showed a less altered

TABLE 1 - Means and SD of \%SMHC and wear $(\mu \mathrm{m})$ for the experimental groups $(n=5)$.

\begin{tabular}{l|c|c}
\hline \hline $\begin{array}{c}\text { Experimental } \\
\text { groups }\end{array}$ & \%SMHC & Wear \\
\hline GI-erosion & $91.61 \pm 3.68^{\mathrm{a}}$ & $2.77 \pm 1.21^{\mathrm{a}}$ \\
\hline $\begin{array}{l}\text { GII-erosion }+ \\
\text { abrasion }\end{array}$ & $58.77 \pm 11.47^{\mathrm{b}}$ & $3.80 \pm 0.91^{\mathrm{b}}$ \\
\hline \hline
\end{tabular}

Values in the same column followed by distinct lower-case superscript letters indicate statistical significance $(\mathrm{p}<0.05)$.

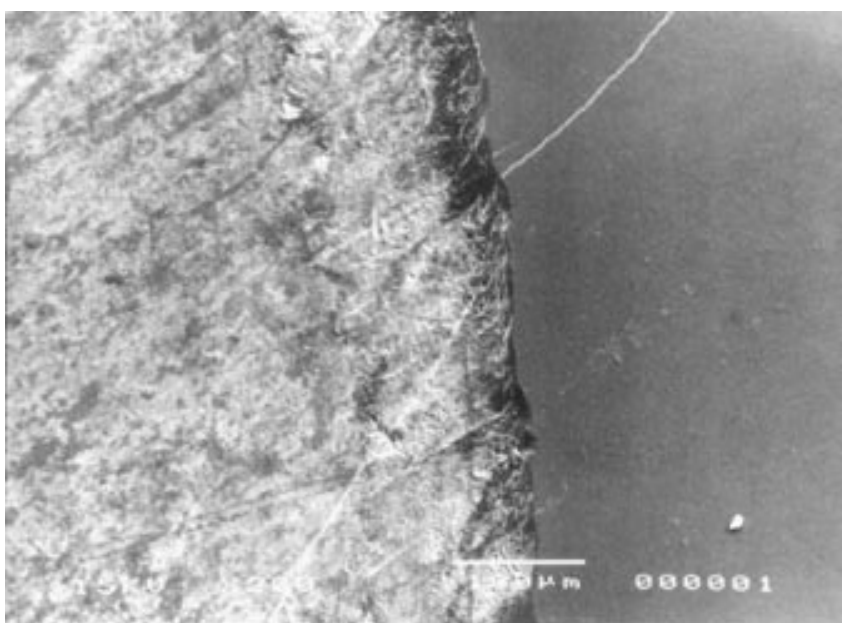

FIGURE 3 - Control-test area of specimen from group II (erosion + abrasion). The bar represents $100 \mu \mathrm{m}$ (200 X). 
Rios D, Honório HM, Magalhães AC, Buzalaf MAR, Palma-Dibb RG, Machado MAAM, Silva SMB. Influence of toothbrushing on enamel softening and abrasive wear of eroded bovine enamel: an in situ study. Braz Oral Res 2006;20(2):148-54.

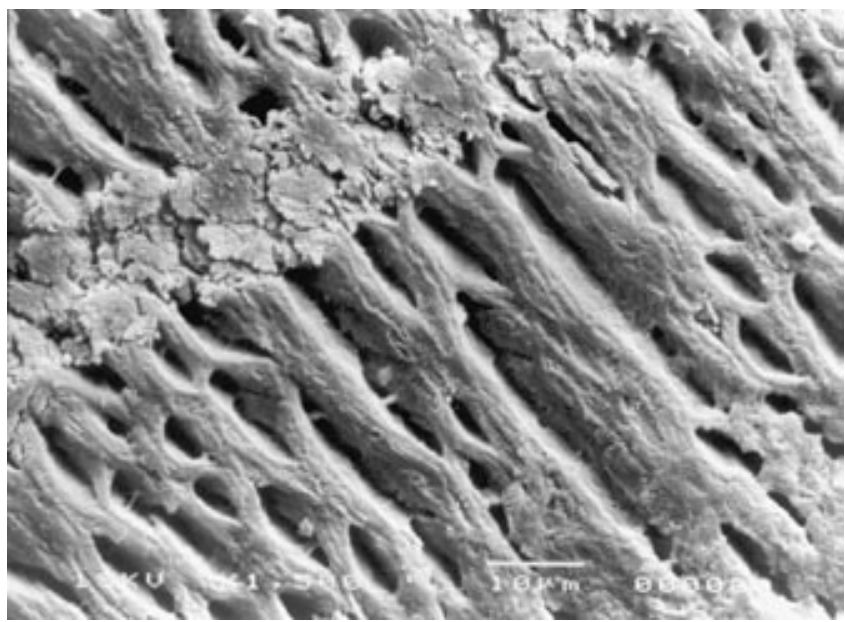

FIGURE 4 - Experimental area of specimen from group I (erosion). Severe erosion with prism core dissolution. The bar represents $10 \mu \mathrm{m}(1,500 \mathrm{X})$.

surface, more similar to that of the control area (Figure 5).

\section{DISCUSSION}

In order to simulate the everyday situation as closely as possible, an in situ model was chosen in the present study to test erosion plus abrasion on enamel. Bovine enamel was used in agreement with other studies ${ }^{10,11}$. It was observed that microhardness of this tissue is similar to that of humans, but bovine enamel is more affected by acid than is human enamel ${ }^{3,10}$. In addition, removal of the outermost layer of enamel during specimen preparation was thought to have influenced the severity of the erosion process ${ }^{23}$. Therefore the results presented may be overestimated when compared to those of human teeth in vivo, but since the study is capable of replicating the biological variations of the oral environment, the results must be an indicator of what would occur in vivo.

The formation of a salivary pellicle during the first $12 \mathrm{~h}$ aimed to protect the underlying enamel against erosive destruction. The erosive challenge was performed extraorally because the authors did not want to take the risk of demineralizing the natural teeth of the volunteers by frequent exposure to large amounts of acidic solution.

However, it was previously demonstrated that after rinsing with acidic solutions the $\mathrm{pH}$ at tooth surfaces drops below the critical $\mathrm{pH}$ for enamel dissolution for a period of about $2 \mathrm{~min}^{24}$. Moreover, rinsing with acidic beverages generates a sharp rise

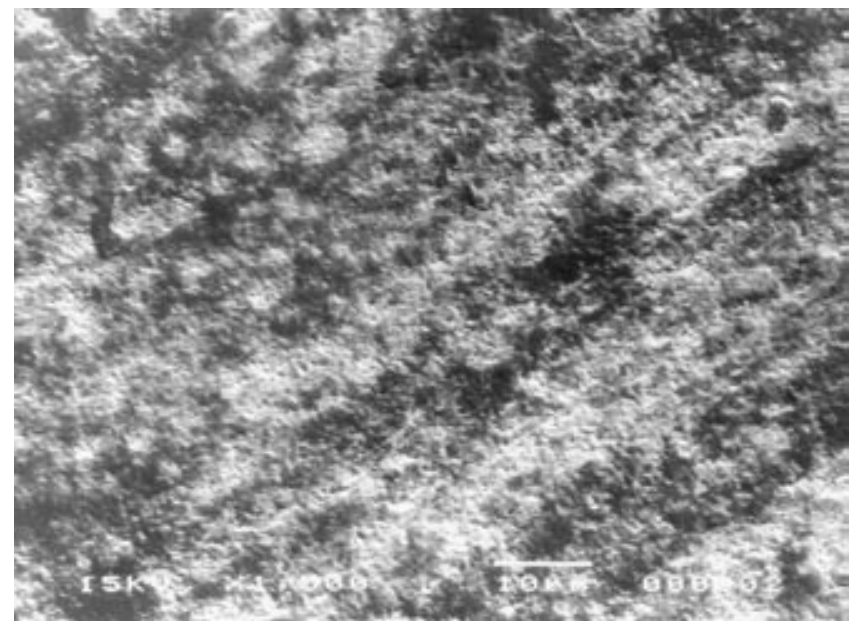

FIGURE 5 - Experimental area of specimen from group II (erosion + abrasion). Surface roughening when compared with control area, which is smoother. The bar represents $10 \mu \mathrm{m}(1,500 \mathrm{X})$.

in parotid salivary flow rate, which returns to resting levels only within $6 \mathrm{~min}^{24}$. Considering these interactions of acidic substances with saliva, the participants of the present study were instructed to take one sip of the beverage before reinsertion of the intraoral appliance after the extraoral immersion of the specimens.

The volunteers were instructed not to touch the enamel blocks with the tongue, in order to avoid the abrasive effect of the tongue ${ }^{13}$. To standardize the parameter abrasion as much as possible, the specimens were brushed extraorally with a soft end-tufted toothbrush and the volunteers were trained and instructed to carefully perform this procedure with 30 brushing strokes without applying force ${ }^{15,18}$. It may be assumed that this brushing of a single tooth occurs only in the case of performing meticulous tooth cleaning. This fact should be considered when interpreting the total amount of enamel abraded recorded for the specimens in the present study.

The association of profilometric and microhardness analyses allowed the understanding of the erosive phenomenon and its association with abrasion $^{4,6}$. The enamel blocks subjected to erosion alone presented higher percentage of microhardness change than the blocks subjected to erosion plus toothbrushing. On the other hand, toothbrushing of the enamel previously eroded promoted higher wear than erosion alone.

In order to explain these findings, the following hypothesis was formulated. Erosion may have resulted from some direct loss of the superficial 
Rios D, Honório HM, Magalhães AC, Buzalaf MAR, Palma-Dibb RG, Machado MAAM, Silva SMB. Influence of toothbrushing on enamel softening and abrasive wear of eroded bovine enamel: an in situ study. Braz Oral Res 2006;20(2):148-54.

enamel layer, and in addition, may have softened the underlying layer, thus resulting in lower microhardness. This softened layer was vulnerable to mechanical forces, and was removed by the brushing procedure, resulting in exposure of a harder enamel surface. The scanning electron microscopy images also corroborate this hypothesis ${ }^{26}$. Due to this fact, the wear increased when eroded enamel was subjected to abrasion, but the \%SMHC was lower when compared to that of erosion alone. This hypothesis is supported by previous investigations, which showed that softened enamel is extraordinarily susceptible to toothbrushing performed immediately after an erosive challenge ${ }^{4,5,8,18}$.

The results of the present study show that toothbrushing can potentialize the effects of an erosive challenge. Thus, a therapy to minimize this synergistic effect is required. Studies have shown that beverage modification, salivary stimulation by

\section{REFERENCES}

1. Addy M, Hunter ML. Can tooth brushing damage your health? Effects on oral and dental tissues. Int Dent $\mathrm{J}$ 2003;53:177-86.

2. Amaechi BT, Higham SM. Eroded enamel lesion remineralization by saliva as a possible factor in the site-specificity of human dental erosion. Arch Oral Biol 2001;46:697-703.

3. Amaechi BT, Higham SM, Edgar WM. Factors influencing the development of dental erosion in vitro: enamel type, temperature and exposure time. J Oral Rehabil 1999;26:62430.

4. Attin T, Buchalla W, Gollner M, Hellwig E. Use of variable remineralization periods to improve the abrasion resistance of previously eroded enamel. Caries Res 2000;34:48-52.

5. Attin T, Knofel S, Buchalla W, Tutuncu R. In situ evaluation of different remineralization periods to decrease brushing abrasion of demineralized enamel. Caries Res 2001;35:21622.

6. Attin T, Koidl V, Buchalla W, Schaller HG, Kielbassa AM, Hellwig E. Correlation of microhardness and wear in differently eroded bovine dental enamel. Arch Oral Biol 1997;42:243-50

7. Attin T, Zirkel C, Hellwig E. Brushing abrasion of eroded dentin after application of sodium fluoride solutions. Caries Res 1998;32:344-50.

8. Davis WB, Winter PJ. The effect of abrasion on enamel and dentine and exposure to dietary acid. Br Dent $\mathrm{J}$ 1980;148:253-6.

9. Eccles JD. Tooth surface loss from abrasion, attrition and erosion. Dent Update 1982;9:373-81.

10. Featherstone JD, Mellberg JR. Relative rates of progress of artificial carious lesions in bovine, ovine and human enamel. Caries Res 1981;15:109-14.

11. Fushida CE, Cury JA. Estudo in situ do efeito da freqüência de ingestão de Coca-Cola na erosão do esmaltedentina e reversão pela saliva. Rev Odontol Univ São Paulo $1999 ; 13(2): 127-34$ a chewing-gum and consumption of cheese or milk after the acid attack could decrease erosion ${ }^{12,16,19}$. Other studies have demonstrated that using fluoride mouth rinses before brushing procedures, or waiting at least one hour to brush the teeth after an erosive challenge, could decrease the enamel wear $4,5,7,15,18,21$. However, further studies should be conducted to establish preventive measures to decrease alterations by eroded enamel subjected to abrasion.

\section{CONCLUSIONS}

The enamel superficial wear was more pronounced when erosion was subjected to toothbrushing abrasion. However, the surface softening was smaller, when toothbrushing was performed, due to the removal of the altered superficial layer by erosion.
12. Gedalia I, Dakuar A, Shapira L, Lewinstein I, Goultschin J, Rahamim E. Enamel softening with Coca-Cola and rehardening with milk or saliva. Am J Dent 1991;4:1202 .

13. Gregg T, Mace S, West NX, Addy M. A study in vitro of the abrasive effect of the tongue on enamel and dentine softened by acid erosion. Caries Res 2004;38(6):557-60.

14. Grenby TH. Methods of assessing erosion and erosive potential. Eur J Oral Sci 1996;104(2):207-14.

15. Hara AT, Turssi CP, Teixeira EC, Serra MC, Cury JA. Abrasive wear on eroded root dentine after different periods of exposure to saliva in situ. Eur J Oral Sci 2003;111:4237.

16. Hughes JA, West NX, Parker DM, Newcombe RG, Addy M. Development and evaluation of a low erosive blackcurrant juice drink. 3. Final drink and concentrate, formulae comparisons in situ and overview of the concept. J Dent 1999;27:345-50.

17. Imfeld T. Dental erosion. Definition, classification and links. Eur J Oral Sci 1996;104:151-5.

18. Jaeggi T, Lussi A. Toothbrush abrasion of erosively altered enamel after intraoral exposure to saliva: an in situ study. Caries Res 1999;33:455-61.

19. Lewinstein I, Ofek L, Gedalia I. Enamel rehardening by soft cheeses. Am J Dent 1993;6:46-8.

20. Litonjua LA, Andreana S, Bush PJ, Cohen RE. Tooth wear: Attrition, erosion and abrasion. Quintessence Int 2003;34:435-46.

21. Lussi A, Jaeggi T, Megert B. Effect of various fluoride regimes on toothbrush abrasion of softened enamel in situ. Caries Res 2004;38:393.

22. Lussi A, Jaeggi T, Zero D. The role of diet in the aetiology of dental erosion. Caries Res 2004;38:34-44.

23. Meurman JH, Frank RM. Progression and surface ultrastructure of in vitro caused erosive lesions in human and bovine enamel. Caries Res 1991;25:81-7. 
Rios D, Honório HM, Magalhães AC, Buzalaf MAR, Palma-Dibb RG, Machado MAAM, Silva SMB. Influence of toothbrushing on enamel softening and abrasive wear of eroded bovine enamel: an in situ study. Braz Oral Res 2006;20(2):148-54.

24. Millward A, Shaw L, Harrington E, Smith AJ. Continuous monitoring of salivary flow rate and $\mathrm{pH}$ at the surface of the dentition following consumption of acidic beverages. Caries Res 1997;31:44-9.

25. Moss SJ. Dental erosion. Int Dent J 1998;48:529-39.

26. Neves Ade A, Castro R de A, Coutinho ET, Primo LG. Microstructural analysis of demineralized primary enamel after in vitro toothbrushing. Pesqui Odontol Bras 2002;16:137-43.

27. Peterson G, Bratthall D. The caries decline: a review of reviews. Eur J Oral Sci 1996;104:436-43.

28. Scheutzel P. Etiology of dental erosion-intrinsic factors. Eur J Oral Sci 1996;104:178-90.

29. Traebert J, Moreira EA. Behavioral eating disorders and their effects on the oral health in adolescence. Pesqui Odontol Bras 2001;15:359-63.

30. West NX, Hughes JA, Parker DM, Newcombe RG, Addy M. Development and evaluation of a low erosive blackcurrant juice drink. 2. Comparison with a conventional blackcurrant juice drink and orange juice. J Dent 1999;27:341-4.

Received for publication on Sep 26, 2005

Sent for alterations on Nov 30, 2005 Accepted for publication on Feb 20, 2006 